\title{
First Record of Bremia lactucae Infecting Sonchus oleraceus and Sonchus asper in Brazil and its Infectivity to Lettuce
}

\author{
B. S. Vieira and R. W. BARRETo \\ Authors' address: Departamento de Fitopatologia, Universidade Federal de Viçosa, CEP 36571000 Viçosa, MG, Brazil \\ (correspondence to R.W. Barreto. E-mail: rbarreto@ufv.br)
}

Received June 13, 2005; accepted October 5, 2005

Keywords: Lactuca sativa, downy mildew, weed, common sowthistle, spiny sowthistle, Peronosporaceae, Oomycota

\begin{abstract}
Bremia lactucae is recorded for the first time causing downy mildew on common sowthistle (Sonchus oleraceus) and spiny sowthistle (Sonchus asper) in Brazil. The disease and etiological agent are described. Pathogencity of sporangia obtained from $S$. oleraceus was tested on 12 species belonging to the Asteraceae, already recorded in the literature as hosts of B. lactucae, and four commonly cultivated varieties of lettuce. All four cultivars of lettuce, $S$. oleraceus and $S$. asper showed symptoms of the disease and sporulation of the pathogen 5 days after inoculation. It has been observed that the disease occurs on Sonchus spp. throughout the year in Viçosa (state of Minas Gerais), being more common on these two hosts than on lettuce. Both weeds are very common invaders of vegetable growing areas in Brazil. This indicates that those two hosts for the fungus may be important inoculum reservoirs for disease occurring in lettuce, highlighting the need for control of these weeds as part of the procedures aimed at controlling this disease. These results are also in agreement with the views that B. lactucae is split into host-specific infra-specific taxa. Lettuce and sowthistles are regarded as closely related, belonging to the same subfamily and tribe in the Asteraceae (Subfamily Cichorioideae: Tribe Lactuceae).
\end{abstract}

\section{Introduction}

Lettuce (Lactuca sativa L.) is one of the most important vegetable crops in the world and is also ranked among the most important vegetables in Brazil, with a national production of approximately 321.000 ton/year IBGE (1996). This species belongs to the Asteraceae and was originated from wild forms that are still found in nature in Europe and Asia. Selection of cultivars yielded varieties that now can be cultivated throughout the year in tropical and subtropical countries such as in Brazil (Filgueira, 2000). Among the limiting factors for this crop in Brazil there is a series of fungal pathogens, including Bremia lactucae Regel, the etiological agent of downy mildew (Mendes et al., 1998). Downy mildew is a disease of lettuce of worldwide distribution and regarded as one of the worst diseases of this crop, in soil and soilless lettuce crops (Zambolim et al., 2000). The disease is particularly damaging under high humidity and cool temperature conditions when dew formation is favoured (Pavan et al., 2005). All of the phases of development of the lettuce can be affected, from seedlings to the adult stage.

Bremia lactucae (Oomycota: Peronosporaceae) is, like other members of its family, a highly specialized, obligate plant pathogen, that causes downy mildews in many different host plants. In the absence of their primary host plants these fungi usually rely on their resistant sexual spores (oospores) or on alternate hosts for survival. Much research has been done on B. lactucae and the world literature contains abundant information about the fungus and the disease it causes (Paaske, 2000; Wu et al., 2000; Blancard and Maisonneuve, 2003). Little attention appears to have been paid, nevertheless, to the relevance of wild or weedy hosts as reservoirs for disease outbreaks in lettuce plantations. In the main Brazilian plant pathology textbook (Pavan et al., 2005) lists as general management methods recommended for this disease, the selection of well drained soils for cultivation, avoidance of low humid dew-formation-prone areas, crop rotation, destruction of crop residues, use of resistant varieties and fungicide sprays. Although emphasis of recommendations is on management of this disease with chemical methods this is somewhat restricted by the short cycle of the crop coupled with the relatively long period that should elapse between fungicide application and harvest for most recommended products. In Brazil fungicides registered for the control of downy mildew of lettuce are only recommended for nursery production (Zambolim et al., 2000). Interestingly, no mention is made of a need to eradicate other hosts for this fungus. It is nevertheless known that this fungus has a wide list of host in the Asteraceae (Crute and 
Dixon, 1981; Lebeda et al., 2002; Lebeda and Petrzelová, 2004). According to Morgan (1981) there are records of $B$. lactucae attacking at least 230 different host species in the Asteraceae. In Brazil (Mendes et al., 1998) listed only artichoke (Cynara scolymus), additionally to lettuce, as a host for this fungus.

For nearly 10 years we observed B. lactucae attacking two common exotic weeds in the campus of the Universidade Federal de Viçosa, municipality of Viçosa, state of Minas Gerais, Brazil: Sonchus oleraceus L. (common sowthistle; local name serralha) and Sonchus asper (L.) Hill (spiny sowthistle; local name serralha-áspera). In fact, the occurrence of abundant sporulation of B. lactucae on $S$. oleraceus is so consistent throughout the year that this became a favourite source of specimens to be used in classes on downy mildews at the university (Departamento de Fitopatologia, Universidade Federal de Viçosa). Occurrence of downy mildew on lettuce in Viçosa was observed to be less consistent and usually yield an inferior teaching material as compared with the same disease on $S$. oleraceus. This information remained unpublished, nevertheless, until additional information on this hostpathogen association, particularly a confirmation of the pathogenicity of the isolate from Sonchus to lettuce, became available.

Both species of Sonchus have a widespread world distribution and are also widespread in Brazil (Lorenzi, 2000). They are considered to be native to Europe and North Africa and are common problem as invaders of many crops, particularly of open vegetable fields and are known to serve as reservoirs for several viruses and nematodes attacking crops (Holm et al., 1991; Kissmann and Groth, 1999). Their suspected relevance as reservoirs for the downy mildew pathogen would require confirmation of the pathogenicity of such isolates to lettuce. It is known that B. lactucae can have highly specialized strains and some authors have proposed recognition of such strains at levels of formae specialis or races (Sedlarova et al., 2001; Petrzelova and Lebeda, 2003). In the present publication we are recording the occurrence of this fungus on $S$. oleraceus and $S$. asper in Brazil for the first time and providing some information on the pathogenicity of this fungal population within the Asteraceae.

\section{Materials and Methods}

Record and taxonomic description of B. lactucae associated to $S$. oleraceus and $S$. asper were based on material collected in the campus of the Universidade Federal de Viçosa, which was deposited at the local herbarium. Measurements and photographs were prepared with a light microscope Olympus BX 50, fitted with a camera.

Morgan (1981) provided a long list of hosts for B. lactucae that included members of the following genera: Agoseris, Arctium, Carduus, Carthamus, Centaurea, Cichorium, Cineraria, Cirsium, Crepis, Cynara, Dendroseris, Dimorphotheca, Erechtites, Gaillardia, Gnaphalium, Helichrysyum, Hemistepta, Hieracium,
Table 1

Host-range test of the strain of B. lactucae from $S$. oleraceus

Plant species Result of inoculations

Articum minus (Hill.) Bernh.

Chicorium sp. L.

Chicorium intybus $\mathrm{L}$.

Crepis japonica $\mathrm{L}$.

Cynara scolymos L.

Dimorphoteca sinuata $\mathrm{L}$.

L. sativa L. cv. Mimosa

L. sativa L. cv. Grandes lagos

L. sativa L. cv. Quatro estações

L. sativa L. cv. Branca

Senecio douglasii L.

$S$. asper (L.) Hil

S. oleraceus $\mathrm{L}$.

Solidago sp. (Vaill.) L.

Solidago chilensis Meyen

Taraxacum officinale Weber

-
-
-
-
-
-
+
+
+
+
-
+
+
-
-
-

+ , disease symptoms and sporulation present on inoculated plants; -, disease symptoms and sporulation absent on inoculated plants.

Hypochoeris, Facobaea, Krigia, Lactuca, Lagoseris, Lapsana, Lappa, Leontodon, Mulgedium, Nabalus, Picris, Prenanthes, Rhodanthe, Saussurea, Senecio, Solidago, Sonchus, Taraxacum and Tragopogon. For practical reasons, only a few selected species of Asteraceae were included in the simplified host-range test performed in this study (Table 1).

Inoculum of B. lactucae was obtained from sporulating colonies of severely infected $S$. oleraceus leaves collected in the campus of the Universidade Federal de Viçosa. Sporangia were collected with the aid of a spore collector adapted to a vacuum pump. These were sucked and deposited in the interior of a test tube containing sterile distilled water. After collecting the sporangia, concentration of the sporangial suspension was adjusted to $1 \times 10^{5}$ sporangia $/ \mathrm{ml}$ with the help of a hemocytometer. Test plants were brush-inoculated with the suspension on both sides of all leaves of the plants. After the inoculation, the plants were maintained in a dew chamber with a temperature of $18^{\circ} \mathrm{C}$, for $24 \mathrm{~h}$, and transferred to a greenhouse where they were observed daily for the appearance of symptoms. Plants brushed with sterile water served as controls. The experiment was accomplished with three repetitions, each repetition consisting of a pot containing a plant.

\section{Results and Discussion}

The fungus produced on $S$. oleraceus plants typical downy mildew symptoms (Fig. 1). Disease on living leaves started adaxially as yellowish lesions and evolved into vein-delimited roughly angular areas, 5-9 $\mathrm{mm}$ diameter that coalesced and became brown leading to blight of extensive areas or whole leaves with age; abaxially - corresponding to the lesions on the upper side - abundant white sporulation (sporangiophores and sporangia) were often observed. Fungal structures were typical of B. lactucae (Fig. 2): sporangiophores hipophylous, emerging from stomata, 


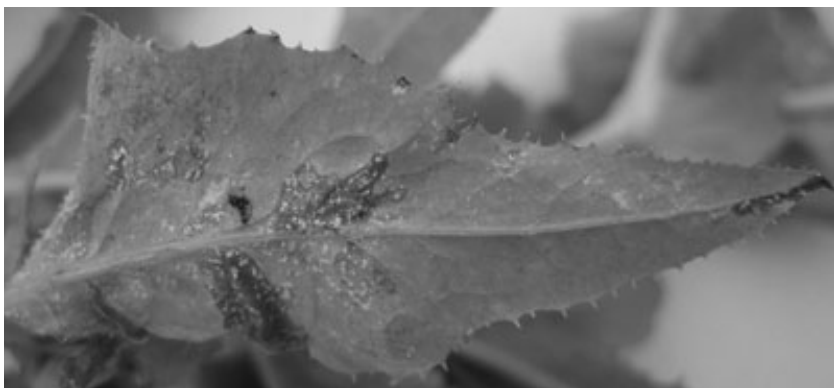

Fig. 1 Abaxial side of a leaf of $S$. oleraceus showing downy mildew symptoms and sporulation of B. lactucae

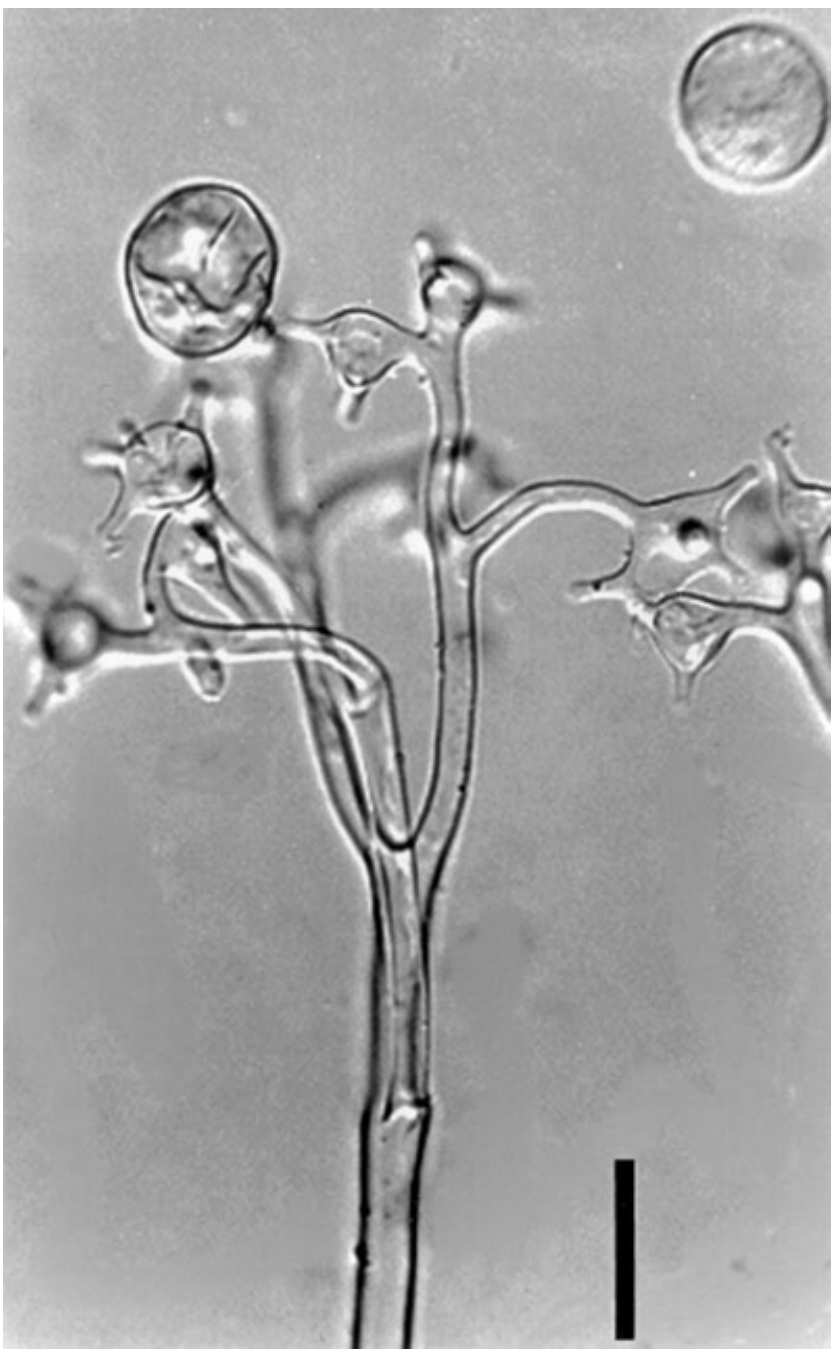

Fig. 2 Sporangiophores and sporangia of B. lactucae obtained from S. oleraceus. Bar $=25 \mu \mathrm{m}$

straight, branching dicotomically, 430-990 × 7-16 $\mu \mathrm{m}$, ending in apophises, each bearing 4-5 sterigmata from which sporangia were formed, hyaline, smooth; sporangia spherical, 14-25 $\mu \mathrm{m}$, hyaline, smooth.

VIC 28747, Campus of the Universidade Federal de Viçosa, Minas Gerais, Brazil, 19th April 2004 on S. oleraceus, B. S. Vieira; VIC 27799; Campus of the

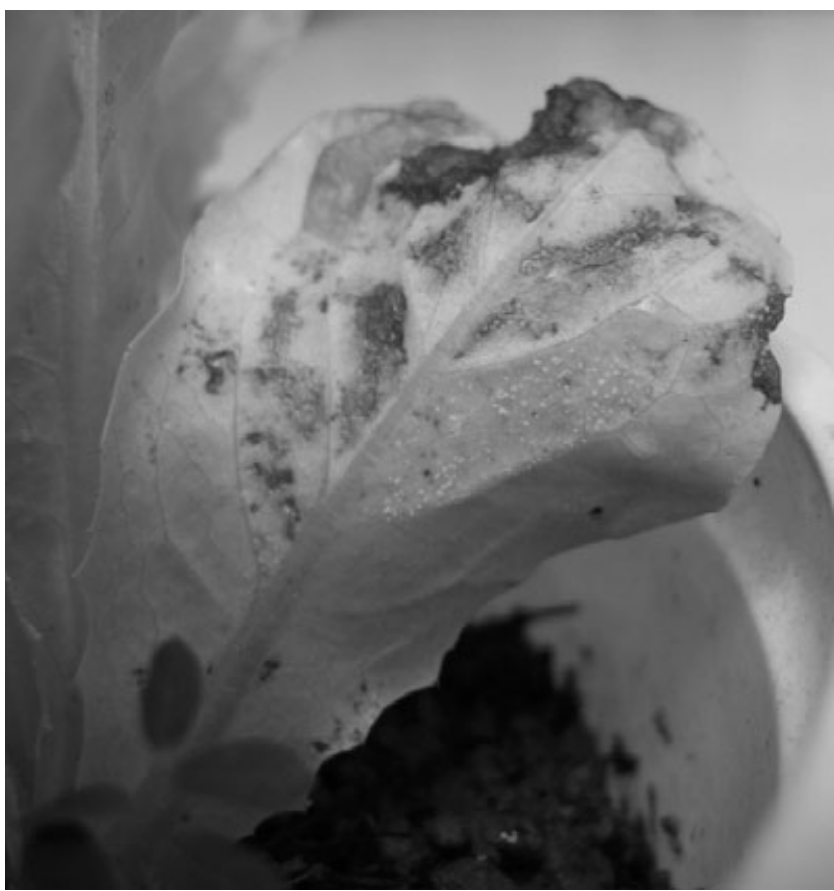

Fig. 3 Sporulation of B. lactucae on the abaxial side of leaves of L. sativa $\mathrm{L}$. cv. Mimosa after inoculation with the strain obtained from sowthistle

Universidade Federal de Viçosa, Minas Gerais, Brazil, 12th June 2004 on S. asper, B. S. Vieira.

Symptoms of $B$. lactucae infection and sporulation on test plants involved in the host-range test were noticeable 5 days after the inoculation. Only the four cultivars of L. sativa and the two species of Sonchus, among the plants included in the test, were susceptible to the isolate from $S$. oleraceus. For these species abundant sporulation was observed abaxially on inoculated leaves (Fig. 3). All the other 10 species included in the test did not become infected (Table 1). This is the first record of the host-pathogen association between B. lactucae and both species of Sonchus for Brazil.

Results of the host-range test are also in agreement with the views that $B$. lactucae is split into host-specific infra-specific taxa. Lettuce and sowthistles, which are regarded as closely related, belonging to the same subfamily and tribe in the Asteraceae (Subfamily Cichorioideae: Tribe Lactuceae) became infected whereas other members of the family involved in the test were not susceptible.

The confirmation of the pathogenicity of the strain from Sonchus to lettuce coupled with the ubiquity of both plant species in vegetable growing areas in Brazil and the fact that oospores of B. lactucae are not known to be formed in Brazil suggest that these hosts may be of great importance for survival and as source of primary inoculum for downy mildew epidemics in lettuce crops in this country. This work indicates that in order to achieve an effective control of this disease in lettuce plantations, control of local populations of 
sowthistles should be contemplated, as part of integrated mildew management.

\section{Acknowledgements}

The authors wish to acknowledge the Coordenação de Aperfeiçoamento de Pessoal de Nível Superior (Capes) and the Conselho Nacional do Desenvolvimento Científico e Tecnológico (CNPq) for financial support

\section{References}

Blancard D, Lot H, Maisonneuve B. Diseases of Lettuces: Identification, Detection and Control. Maladies des Salads: Identifier, Connaitre et Maitriser. Paris, France, INRA Editions, 2003.

Crute IR, Dixon GR. Downy mildew diseases caused by the genus Bremia Regel. In: Spencer DM (ed.), The Downy Mildews, London, UK, Academic Press, 1981, pp. 421-460.

Filgueira FAR. Novo Manual de Olericultura: Agrotecnologia Moderna na Producão e Comercialização de Hortaliças, Viçosa, Brasil, Editora Viçosa, UFV, 2000.

Holm LG, Plucknett DL, Pancho JV, Herberger JP. The World's Worst Weeds: Distribution and Biology, Malabar, FL, Krieger Publishing Company, 1991.

IBGE (1996) http://WWW.IBGE.GOV.BR/.

Kissmann KG, Groth D. Plantas Infestantes e Nocivas, Vol. 2. São Paulo, Brasil, BASF, 1999.

Lebeda A, Petrzelová I. (2004) Variation and distribution of virulence phenotypes of Bremia lactucae in natural populations of Lactuca serriola. Plant Pathol 53:316-324.

Lebeda A, Pink DAC, Astley D. Aspects of the interactions between wild Lactuca spp. and related genera and lettuce downy mildew (Bremia lactucae). In: Spencer-Phillips PTN, Gisi U, Lebeda A (eds), Advances in Downy Mildew Research, Dordrecht, Netherlands, Kluwer Academic Press, 2002, pp. 85-117.

Lorenzi H. Plantas Daninhas do Brasil: Terrestres, Aquáticas, Parasitas e Tóxicas, 3rd edn, São Paulo, Brasil, Nova Odessa, Instituto Plantarum, 2000.

Mendes MAS, Silva VL, Dianese JC et al. Fungos em plantas no Brasil, Brasília, Brasil, Embrapa-SPI/Embrapa-Cenargen, 1998.

Morgan WM. CMI Descriptions of Pathogenic Fungi and BacteriaBremia Lactucae, Vol. 682, UK, Kew, Surrey, 1981, pp. 1-3.

Paaske K. Strategy Trials for Control of Mildew (Bremia lactucae). Havebrug, Danmark, 18th Danish Plant Protection Conference, III DJF-Rapport, 2000, No. 17, pp. 97-105.

Pavan MA, Krause-Sakate R, Kurozawa C. Doenças da Alface. In: Kimati H, Amorim L, Filho AB, Camargo LEA, Rezende JAM (eds), Manual de Fitopatologia. Doenças das Plantas Cultivadas, Vol. 2, São Paulo, Brasil, Editora Agronômica Ceres, 2005, pp. 27-35.

Petrzelova I, Lebeda A. (2003) Distribution of compatibility types and occurrence of sexual reproduction in natural populations of Bremia lactucae on wild Lactuca serriola plants. Acta Phytopathol Entom Hung 38:43-52.

Sedlarova M, Lebeda A, Pink DAC. (2001) The early stages of interactions between effective and non-effective race-specific genes in Lactuca sativa, wild Lactuca spp. and Bremia lactucae (race NL 16). Z Pflanzenkr Pflanzenschutz 108:5,477-489.

Zambolim L, Do vale FXR, Costa H. Controle de Doenças de Plantas - Hortaliças, Vol. 1. Viçosa, Brasil, Editora Viçosa, UFV, 2000 .

Wu BM, Subbarao KV, Bruggen van AHC, Van Bruggen AHC (2000) Factors affecting the survival of Bremia lactucae sporangia deposited on lettuce leaves. Phytopathology 90:827-833 